\title{
Mineralogical and metamorphic evolution of the Proterozoic mafic magmatic rocks of the basal Aravalli sequence, Rajasthan, India
}

\author{
A.M. GRABARCZYK ${ }^{1}$, J.B. WISZNIEWSKA ${ }^{2}$, \\ E. KRZEMINSKA ${ }^{2}$ \\ ${ }^{1}$ Faculty of Geology, University of Warsaw, \\ Żwirki i Wigury 93,02-089 Warsaw, Poland \\ anna.grabarczyk@student.uw.edu.pl \\ ${ }^{2}$ Polish Geological Institute - National Research Institute \\ 4,Rakowiecka str., 00-975 Warsaw, Poland
}

Field, mineralogical and geochemical data for metavolcanic rocks of the Aravalli sequence (Aravalli Craton) in Rajasthan, NW India, have been presented. Due to the field research pillow lava structures, indicating their eruption in a marine environment, have been discovered. Primary mineralogy has shown complete alteration during postmagmatic processes associated with the greenschist to lower amphibolite facies metamorphism. The $\mathrm{Ti}$ and $\mathrm{Al}$ content of $\mathrm{Ca}$ amphiboles are in positive correlation with temperature and pressure. Combined isoplots have shown temperature not exceeding of $550^{\circ} \mathrm{C}$, for the pressure in range 1.5- $2.5 \mathrm{GPa}$. The spinifex-like texture of the pillow-lava surface evidenced fast quenching conditions. Primary mineralogy have been then overprinted by plagioclase-chlorite-amphibole-epidote mineral assemblage. No relicts of olivine or clinopyroxene are present. The composition of pillow lavas are komatiitic and high-Fe tholeiitic basalts with $\mathrm{SiO}_{2}=36.5-54.4$ wt. $\%$ and $\mathrm{Mg} /\left(\mathrm{Mg}+\mathrm{Fe}_{\text {tot }}\right) \times 100=26-57$ with $\mathrm{MgO}$ content ranging from 5.3 to 16.9 wt.\%. The rocks have shown LILE and LREE enrichment. Chondrite normalized REE patterns for the Aravalli pillow lava are nearly flat with $(\mathrm{La} / \mathrm{Sm})_{\mathrm{N}}=1.48$ $2.80,(\mathrm{Gd} / \mathrm{Yb})_{\mathrm{N}}=1.41-2.67$. The pillow lava geochemical characteristics are similar to those of high-Fe tholeiitic basalts reported in a previous works from this area [1,2]. The trace element systematics with the negative $\mathrm{Nb}, \mathrm{P}$ and $\mathrm{Zr}$ anomalies of the basalts reflect the crustal contamination signatures. The Aravalli rocks can be treated as the result of island arc magmatism related to the subduction and accretion of the volcanic arcs [1].

The research was financed from PGI-NRI grant no. 62.9012.2012.00.0

\section{References}

[1]Ahmad et al. 2008, Precambrian Research, 162, 150-159.

[2]Wiszniewska et al. 2009, $2^{\text {nd }}$ Int. Conf. PCGT India,10-12 